\title{
Selective anticancer activity of $\beta$-lactams derived from polyaromatic compound
}

\author{
BIMAL K. BANIK ${ }^{1}$ and FREDERICK F. BECKER ${ }^{2}$ \\ ${ }^{1}$ Department of Chemistry, The University of Texas Pan American, Edinburg, TX 78539; \\ ${ }^{2}$ Department of Molecular Pathology, Unit 951, The University of Texas M.D. \\ Anderson Cancer Center, Houston, TX 77504, USA
}

Received July 9, 2009; Accepted December 21, 2009

DOI: 10.3892/mmr_00000257

\begin{abstract}
Currently available anticancer drugs are cytotoxic to normal as well as to neoplastic cells, therefore the synthesis of $\beta$-lactams as new and novel anticancer agents is extremely significant. We previously developed synthetic methods for the preparation of $\beta$-lactams and anticancer agents resulting from polyaromatic amines. There have also been reports on the synthesis and biological evaluation of novel racemic $\beta$-lactams as anticancer agents. In cell cycle analysis, these compounds demonstrated a G2 blockage against sensitive tumor cell lines. In the present study, useful and selective biological activities of chrysene $\beta$-lactams are described.
\end{abstract}

\section{Introduction}

The synthesis of $\beta$-lactams as new and novel anticancer agents is extremely significant and timely since currently available anticancer drugs are cytotoxic to normal as well as to neoplastic cells (1). We have engaged in the development of synthetic methods for the preparation of $\beta$-lactams (2-4) and anticancer agents derived from polyaromatic amines (5). The synthesis and biological evaluation of novel racemic $\beta$-lactams as anticancer agents has also been reported (6). These compounds have demonstrated a G2 blockade in cell cycle analysis against sensitive tumor cell lines $(7,8)$. In the present study, useful and selective biological activities of chrysene $\beta$-lactams are described.

\section{Materials and methods}

$\beta$-lactams and the MTT assay.

Correspondence to: Dr Bimal K. Banik, Department of Chemistry, The University of Texas Pan American, 1201 West University Drive, Edinburg, TX 78539, USA

E-mail:banik@panam.edu

Key words: anticancer agents, $\beta$-lactams, polyaromatic compounds, selectivity

\section{Results}

Three racemic $\beta$-lactams, 1, 2a and $2 \mathrm{~b}$, were prepared following the Staudinger reaction with the corresponding imines (Fig. 1).

It is known that the reaction of acyloxy, alkoxy and nitrogen-containing acid chloride with diaryl imines produces cis- $\beta$-lactams (9). However, in the present study we identified trans- $\beta$-lactams with chrysene as their only products $(1,2 \mathrm{a}$ and $2 b)$.

In vitro cytotoxicity of $\beta$-lactams. The racemic $\beta$-lactams $1,2 \mathrm{a}$ and $2 \mathrm{~b}$ were tested using several human cancer cell lines, with cisplatin as the control (Table I).

\section{Discussion}

The cell growth inhibition data $\left(\mathrm{IC}_{50}\right)$ suggests that the racemic $\beta$-lactam 1 demonstrates reasonable anticancer activity against many human tumor lines, while the activity of the other compounds, $2 \mathrm{a}$ and $2 \mathrm{~b}$, is not promising. The results are of great interest, as all three $\beta$-lactams have $\mathrm{N}$-chrysene system and trans stereochemistry at the ring junction. However, structurally they are different. For example, 1 has a single $\beta$-lactam ring, while $2 \mathrm{a}$ and $2 \mathrm{~b}$ have two $\beta$-lactam rings. In contrast to the activities of 1 , it is notable that $2 \mathrm{a}$ has two acetoxy groups, but remains inactive. Phenoxy compound $2 \mathrm{~b}$ is also inactive. These results indicate that the presence of an acetoxy group in chrysene trans $\beta$-lactam is important and obligatory. Nevertheless, the presence of two such groups can destroy the activity completely. The presence of two phenoxy groups has no positive effects on the anticancer activity of any of the cancer cell lines describe above. The results described herein are unique and warrant further research on anticancer $\beta$-lactams with chrysene and other polyaromatic compounds.

\section{Acknowledgements}

We gratefully acknowledge financial support from the National Institute of Health-SCORE (2S06M008038-37). We are also thankful to the Pharmacology and Analytical Center Facility of the UT M.D. Anderson Cancer Center. 
Table I. In vitro cytotoxicity of $\beta$-lactams on human cancer cell lines $(\mu \mathrm{M})$.

\begin{tabular}{lcccccrr}
\hline Compounds & MDA-231 & BRO & PC-3 & SKOV-3 & HL-60 & K-562 & HT-29 \\
\hline Cisplatin & 12.33 & 7.66 & 4.66 & 5.99 & 1.66 & 2.33 & 16.99 \\
$( \pm)-1$ & 11.98 & 15.70 & 16.32 & 3.90 & 3.64 & 4.33 & 5.66 \\
$( \pm)-2 \mathrm{a}$ & $<20$ & $<20$ & $<20$ & $<20$ & $<20$ & $<20$ & $<20$ \\
$( \pm)-2 \mathrm{~b}$ & $<20$ & $<20$ & $<20$ & $<20$ & $<20$ & $<20$ & $<20$ \\
\hline
\end{tabular}

In vitro cytotoxicity assays were performed at the Pharmacology and Analytic Core Laboratory of the University of Texas M.D. Anderson Cancer Center, Houston. An MTT assay was carried out using the seven human cancer cell lines.

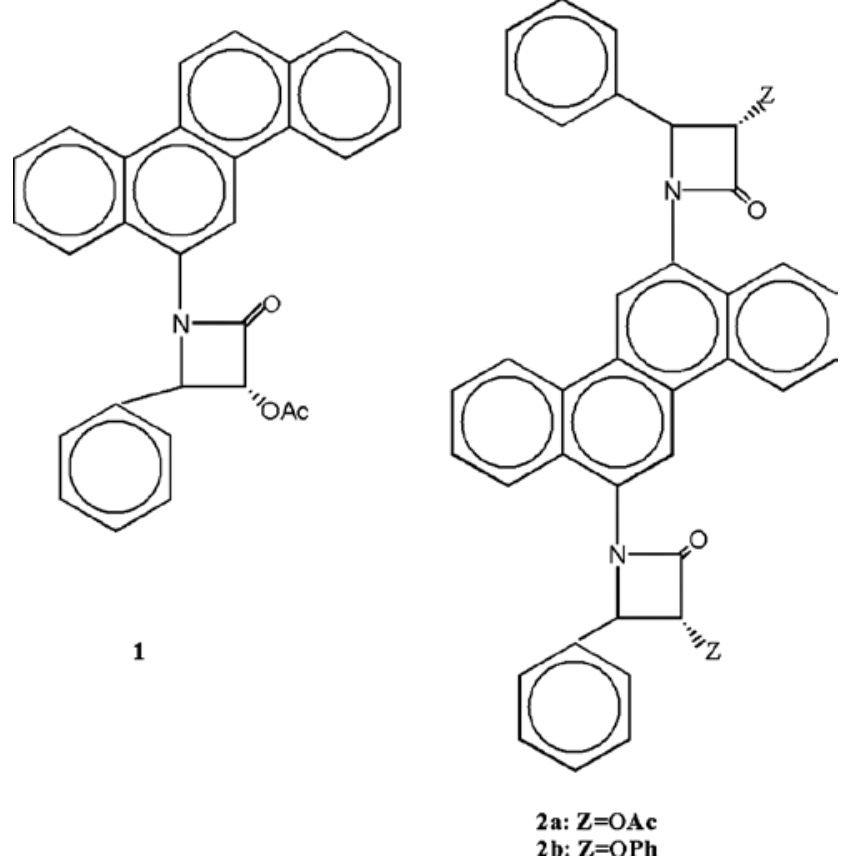

Figure 1. $\beta$-lactams derived from chrysene.

\section{References}

1. Chari RVJ: Targeted delivery of chemotherapeutics: tumoractivated prodrug therapy. Adv Drug Delivery Rev 31: 89-104, 1998.

2. Dasgupta SK and Banik BK: A new entry to N-unsubstituted $\beta$-lactams through a solid-phase approach. Tetrahedron Lett 43: 9445-9447, 2002.

3. Banik BK, Samajdar S and Banik I: A facile synthesis of oxazines by indium-induced reduction-rearrangement of the nitro $\beta$-lactams. Tetrahedron Lett 44: 1699-1701, 2003.

4. Banik BK, Banik I and Hackfeld L: Heterocycles 59: 505-508, 2003.

5. Banik BK and Becker FF: Curr Med Chem 8: 1513-1533, 2001.

6. Banik I, Becker FF and Banik BK: Cycloaddition of naphthalenyl and anthracenyl imines: interesting aspects of the Staudinger reaction. J Med Chem 46: 12-15 2003.

7. Banik BK, Becker FF and Banik I: Synthesis of anticancer ß-lactams: mechanism of action. Bio Org Med Chem 12: 2523-2528, 2004.

8. Banik BK, Banik I and Becker FF: Stereocontrolled synthesis of anticancer $\beta$-lactams via the Staudinger reaction. Bio Org Med Chem 13: 3611-3622, 2005.

9. Bose AK, Manhas MS, Banik BK and Srirajan V: $\beta$-lactams: cyclic amides of distinction. In: The Amide Linkage. Selected Structural Aspects in Chemistry, Biochemistry and Materials Science. Greenberg A, Breneman CM and Liebman JF (eds). Wiley-Interscience, New York, pp 157-214, 2000. 